\title{
ANALYSIS OF INTENTION OF FARMER CARD UTILIZATION USING THEORY OF PLANNED BEHAVIOR
}

\author{
Mutiara Mar Atu Sholihah ${ }^{1, *}$, Moh Djemdjem Djamaludin ${ }^{2}$ \\ ${ }^{1,2}$ Departement of Family and Consumer Science, Faculty of Human Ecology, \\ Bogor Agricultural University, Bogor 16680, Indonesia \\ *Corresponding author: mutiaramaratu@gmail.com
}

\begin{abstract}
One of the Indonesia government's policies in an effort to increase production and productivity of agricultural commodities is to provide subsidized fertilizer for farmers. Currently, the government implements the farmer card program as an effort to facilitate farmers' purchase of subsidized fertilizers. This program will be implemented simultaneously in 2020, however in 2018 there are some areas that have already implemented the farmer card system as trial areas. This study aims to analyze the farmer intention in term of using farmer card in Rancaekek. The analysis used were Theory of Planned Behavior (TPB), statistical analysis, and structural equation modeling (SEM). The research design used cross-sectional study. The sampling method used was probability sampling simple random sampling. Farmers who were interviewed in subdistrict Rancaekek were amounted to 100 out of 1492 farmers. Based on the statistical analysis using SEM, it was found that attitude toward behavior, subjective norm, and perceived behavioral control are significant and have positive effects on the intention of using farmers card. Hence the farmers attitude toward behavior, subjective norm, and perceived behavioral control, are directly proportional to the farmer intention of using farmer card.. All of the variable of Theory of Planned Behavior are determinant factor which influence the intention of using the farmer card. Attitude toward behavior has the largest influence on farmers intention of using farmer card and subjective norm has the smallest influence in farmers intention of using farmer card.
\end{abstract}

Keyword: attitude toward behavior, farmer card, intentions, subjective norms, perceived behavior control.

\section{Introduction}

The agricultural sector plays an important role in food security, even food sovereignty. One of Indonesia's strategic agricultural products that become the main commodity of national food security is rice. Rice is the main food source of the majority of Indonesia's population, hence Indonesian farmers need to pay attention to the quality and quantity of rice produced to meet the needs of the population. Based on Central Bureau of Statistics Indonesia (BPS) (2016) rice production in 2015 was approximately 75,36 million tons of dried unhulled grain (GKG). Annual rice production must meet the needs of 255.182.144 Indonesians (BPS, 2015). 
One of the government policies in an effort to increase production and productivity of agricultural commodities is done through the policy of providing subsidized fertilizer for farmers. In the government's implementation of subsidized fertilizer, there are still problems such as improper targets, infiltration, scarcity, and price increase at the farm level (Agricultural Extension and Development Agency, 2017). Currently, the government implements farmer card program in an effort to facilitate farmers' purchase of subsidized fertilizer. According to the Agricultural Extension and Development Agency (2017), farmer card is a card integrated with banking service access facilities owned by farmers to serve as savings, transactions, loan disbursements to fertilizer subsidy cards.

As a new government program that wants to be to be implemented nationally, analysis on farmers intention on farmer card is required. Certain behaviors by consumers are often determined by the intention of the consumer to perform the behavior (Sumarwan, 2011). One's intentions towards certain behaviors can be constructed from three main dimensions, such as attitude toward behavior, subjective norms, and perceived behavioral control (Ajzen, 2005). These components can be analyzed using the Theory of Planned Behavior (TPB). Theory of Planned Behavior is used by previous researchers to measure intentions and behavior regarding the use of a product or service. Chen et al. (2007) showed that attitude toward behavior, subjective norm, and perceived behavioral control positively influence the intentions in using electronic toll card services. Several other studies have also revealed that attitude toward behavior, subjective norm, and perceived behavioral control have an influence to intention (Yang, 2012: Prihandoko et al., 2012; Burhanudin, 2015; Wang, 2016; Wiyanti \& Untoro, 2016; Alzahrani et al., 2017; Hoeksma, 2017; Wiratmadja et al., 2017).

Based on the explanation above, it is necessary to perform research concerning the intention of using farmer card using theory of planned behavior (TPB) to understand the intention of farmer card usage. Farmer card will be applied in Java Island in 2018 and expected to be implemented in 2020 (Ministry of Agriculture, 2017). The question is whether or not farmer card will be used by all farmers in 2020.

\section{Research conceptual framework}

Conceptual framework in this research is displayed in Figure 1.

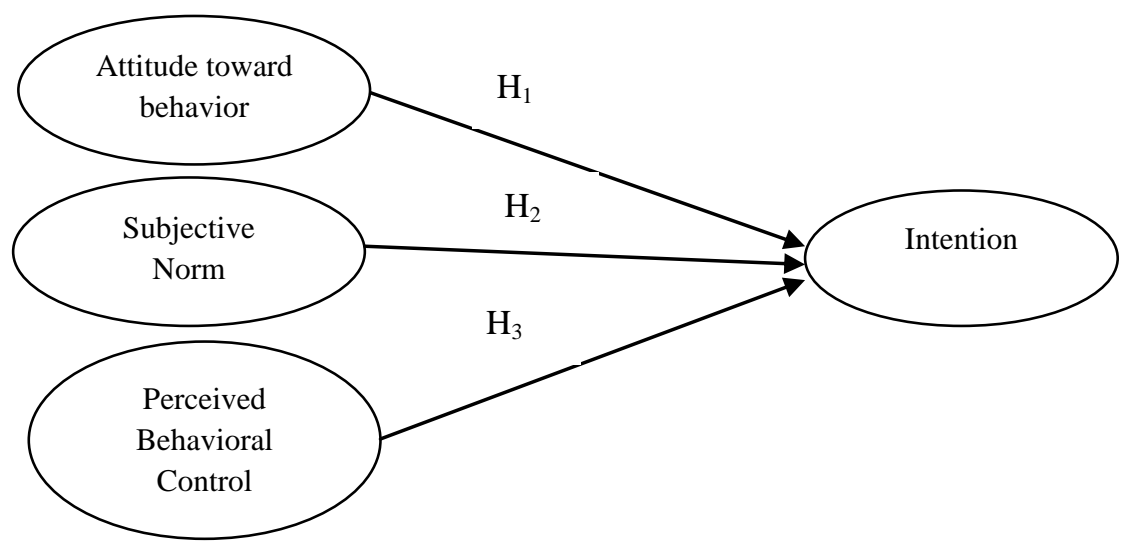

Figure 1. Research conceptual framework 


\section{Methods}

This research used cross sectional study design and was conducted in Rancaekek Sub-District which was selected purposively. This study used quantitative analysis through multivariate analysis and employed structural equation modeling (SEM) using Partial Least Square (PLS). Types of data used in this study are primary data and secondary data. Primary data were obtained from interviews using questionnaires which includes characteristics of farmers (age, sex, education level, production, gross income per season, and land tenure status), attitudes toward behavior, subjective norms, behavior control, and intention. On the other hand, secondary data were obtained from the Department of Agriculture Bandung.

Research population consisted of farmers in Rancaekek. The number of population in this research was 1.492 farmers in Rancaekek. The sample in this research was 100 farmers which was selected by simple random sampling technique. The number of samples used in this study was determined by using the Slovin formula.

The questionnaire used for all variables was developed from Lestari et al. (2013), where attitudes toward behavior contained fourteen statements which consist of seven behavioral belief statements and seven outcomes evaluation statements. Subjective norms were measured by eight statements consist of each of the four normative belief statements and motivation to comply. Behavior control consists of five control belief statements and five power of control statements. The intention of using a farmer card was measured using a single item statement.

\section{Findings}

\section{Characteristics of Farmers}

Both male and female were selected as the sample in this study. The results showed that the majority of farmers were male $(75.0 \%)$. Table 1 shows that the age distribution of farmers was divided based on age grouping by Santrock (2010). The age range of farmers was from 23 years old to 85 years old. Almost half of farmers $(49.0 \%)$ are in the middle adulthood category (40-60 years old) with an average age of 53 years old. Based on the level of education, the average length of education was 7.29 years for farmers who are in the category of elementary school graduate (6 years). The highest percentage of education level was elementary school graduated (34\%). The highest education of farmers in this study was 16 years for the university category.

The rice production per season is shown in Table 2 where the minimum production per season of $100 \mathrm{~kg}$ and a maximum of $40.000 \mathrm{~kg}$ with an average of $3.362 \mathrm{~kg}$. One-third of respondents had production between $1.001 \mathrm{~kg}-2.000 \mathrm{~kg}$ $(37.0 \%)$. Almost all respondents in this study have two harvest seasons a year, but there are some areas in Rancaekek subdistrict that have only one harvest season in a year. The area is located in Tegalsumedang Village and Jelegong Village. 
Measurement model (outer model) evaluation. There are three criteria for data analysis techniques with PLS to assess the outer model, which are convergent validity, discriminant validity, and composite reliability. Convergent validity is the value of loading factor on the latent variable with its indicators (Hair et al., 2014). The outer loadings value is expected to be more than 0.70 . However, according to Vinzi et al. (2010) indicators that have outer loadings values above 0.60 are sufficient. Outer loadings values across all variables do not meet convergent validity because there are some outer loadings values below 0.60 . To meet the convergent validity test, it is necessary to eliminate nine indicators of attitude toward behavior variables statement of 14 indicators and one out of eight indicators of variable of subjective norm needs to be eliminated. one indicator statement from eight. To perceive behavioral control variables, it is necessary to eliminate seven indicators out of statements of ten. After some indicators with outer value of loadings below 0.60 have been eliminated, all indicators have fulfilled convergent validity. A common measure to establish convergent validity at the construct level is average variance extracted (AVE) (Hair et al., 2014). Table 3 shows that variables have an AVE value greater than 0.5 . This shows that all construct variables have met convergent validity.

Discriminant validity is evaluated by comparing the average variance extracted (AVE) root value to be higher and the correlation with any constructs or AVE values higher than the quadratic correlation between constructs (Hair et al., 2014). Based on Table 3, all variables have met the discriminant validity because AVE root value is greater than the correlation with any constructs.

Table 3 Correlation values with any constructs, AVE values and AVE root

\begin{tabular}{lcccccc}
\hline Latent variable & $\begin{array}{c}\text { Attitude } \\
\text { toward } \\
\text { behavior }\end{array}$ & $\begin{array}{c}\text { Subjective } \\
\text { norm }\end{array}$ & $\begin{array}{c}\text { Perceived } \\
\text { behavioral } \\
\text { control }\end{array}$ & Intention & AVE & VAVE \\
\hline $\begin{array}{l}\text { Attitude toward } \\
\text { behavior }\end{array}$ & 0.710 & 0.644 & 0.533 & 0.679 & 0.504 & 0.710 \\
$\begin{array}{l}\text { Subjective norm } \\
\text { Perceived behavioral }\end{array}$ & 0.644 & 0.719 & 0.499 & 0.657 & 0.517 & 0.719 \\
$\begin{array}{l}\text { control } \\
\text { Intention }\end{array}$ & 0.533 & 0.499 & 0.742 & 0.439 & 0.519 & 0.742 \\
\hline
\end{tabular}

Construct reliability can be calculated by composite reliability value of more than 0.60 (Hair et al., 2014). Table 4 shows that composite reliability of attitude variable to behavior, , subjective norm, perceived behavior control, and intention have a value of composite reliability above 0.60 . Therefore no reliability problems were found in the outer model that has been established.

Table 4 Composite reliability of laten variabel

\begin{tabular}{lc}
\hline Latent variable & Composite Reliability \\
\hline Attitude toward behavior & 0.833 \\
Subjective norm & 0.865 \\
Perceived behavioral control & 0.760 \\
Intention & 1.000 \\
\hline
\end{tabular}


Structural model (inner model) evaluation. Inner model is a model that describes the relationship between latent variables that are evaluated with the coefficient of determination $\left(\mathrm{R}^{2}\right)$ and Predictive Relevance $\left(\mathrm{Q}^{2}\right)$. R-square or also called coefficient of determination is a measure of the overall effect in the structural model. R-square value of the latent variable of intention is 0.543 , which means $54.3 \%$ diversity of intention variables can be explained by attitude toward behavior, subjective norm, and perceived behavior control, while the rest is explained by other variables outside the model. Chin (1998) in Garson (2016) states that the R-square value of 0.19 is weak, 0.33 is moderate, and 0.67 is considered satisfactory (good).

Garson (2016) stated, that the predictive relevance $\left(\mathrm{Q}^{2}\right)$ greater than 0 indicates that a model has predictive relevance, if the value of $\mathrm{Q}^{2}$ equals 0 or negative indicates the model is irrelevant to the given prediction. The calculation result of $\mathrm{Q}^{2}$ using Stone-Geisser Q-square is 0.534. This indicates that the predictive value of model prediction conformity is $53.4 \%$ which can be stated that the model has a good predictive relevance $\left(\mathrm{Q}^{2}\right)$.

\section{Test of Hypotheses}

Based on the SEM model that has been created and analyzed using SmartPLS, it can be seen the influence of each variable which summarized in Table 5. The influence of each variable and the direction of the variable relationship is indicated by the original sample value. While the significance of the influence of each variable is shown by the t-statistic value of more than 1.96 and the probability value (p-value) is less than 0.05 or $5 \%$.

The result of the analysis shows that attitude toward behavior has a positive influence on intention with original sample value of 0.346 , which means the higher of the attitude to the behavior in using farmer card will resulted to the increase of the intention in using farmer card. The t-statistic value of attitude variable to behavior is 3,085 , it indicates that the variable has a significant influence on intention. Subjective norm and perceived behavioral control also have a positive effect on intention with the original sample values of 0.255 and 0.284 . The t-statistic value of the subjective norm variable is 2.405 and the behavior control variable is 2,058 , it shows that the variable of subjective norm and perceived behavioral control have significant influence to the intention which means that the higher of the subjective norm and perceived behavioral control of farmer will increase the farmer intention in using farmer card. Thus, there is sufficient empirical evidence to accept the hypothesis (H1, H2, and H3) which expresses attitude toward behavior, subjective norm, and perceived behavioral control positively and significantly mediates the influence of farmer intention in using farmer card.

Tabel 5 Statistical tests of intervariable influences

\begin{tabular}{lcccc}
\hline Path coefecient & & Original Sample & T Statistic & P-values \\
\hline Attitude toward behavior & $\longrightarrow$ Intention & 0.346 & 3.085 & 0.002 \\
Subjective norm & $\longrightarrow$ Intention & 0.255 & 2.405 & 0.017 \\
$\begin{array}{l}\text { Perceived behavioral } \\
\text { control }\end{array}$ & $\longrightarrow$ Intention & 0.284 & 2.058 & 0.040 \\
\hline
\end{tabular}


Figure 4 shows the PLS model of factors which affect the intentions and contributions of each indicator that can be interpreted for attitude variables to the behavior that the more practical the use of Farmer Cards. The farmer card is greatly influenced by the farmers' social status, practicality of fertilizer payment transactions, secured saving, and the economic value. The higher the subjective norm variable or the more the farmers are convinced with the family, peasants, and the head of the farmer group and the more farmers obey it, will resulted to the higher intention to use the farmer card. In addition, higher perceived behavioral control, subsidized fertilizers procurement support, image of the issuing bank of farmers card, and convenient farmer cards, are the driving factors to increase farmers' intention to use farmer card.



Figure 2 PLS model attitudes toward behavior, subjective norms, behavior control, and intentions

\section{Discussion}

The intention of behavior was determined by three major determinants: attitude toward behavior, subjective norm, and perceived behavioral control (Ajzen, 2005). The result of this research found that attitude toward behavior, subjective norm, and perceived behavioral control have significant positive effects to intention of using farmer card. This indicates that the farmers' intention in 
using farmer card is because they consider farmer card as beneficial. In addition, the farmers' intention to use farmer card is due to the support from people around, particularly, peasant farmers and farmer group leaders. Moreover, farmers intention to use farmer card is because they feel able to use the farmer card. The results of this study are in accordance with the theory that proposed by Ajzen (2005) which explained the factors that affect the intention. In addition, this study is in line with Hsu et al. (2016) who examined co-branded airline credit cards in which attitudes toward behavior, perceived behavioral control, and subjective norms have a positive and significant effect on the intention of using co-branded credit cards. Furthermore, this research is also in harmony with research by Lestari et al. (2017) which discovered that attitude toward behavior, subjective norm, and behavior control have significant positive effects on credit card ownership intention in Bogor City.

Attitudes toward behavior has the greatest influence on farmers' intention in using farmer card because it has bigger original sample value than the original value of other sample's variable that is equal to 0.346. This is in line with the research of Yakasai and Jusoh (2015), which stated that attitudes toward behavior proved to be the strongest predictor of intention to use digital coupons. Attitudes toward behavior was perceived from the attitude of farmers, whether using farmer card is considered good or bad by farmers. This can be illustrated by some statements that have passed the model matching test. Most farmers expect farmer card to be easy and practical, and will facilitate the payment transactions of subsidized fertilizers. Agricultural Extension and Development Agency (2017) suggested that there are various benefits of farmer card for farmers, one of them is to generate saving habit. Most farmers think that saving is beneficial because it will make farmers feel safer to face the urgent needs in the future.

Perceived behavioral control is the variable that has the second biggest influence after the attitude toward behavior with original sample value of 0.284 . This is in line with the research of Wiratmadja et al. (2017) who argued that perceived behavioral control variable has significant and positive influence after attitude variable on behavior towards intention to implement organic farming. Perceived behavioral control is seen from the ability of farmers to use farmers card according to their beliefs. More than half of farmers have moderate behavior control, which means farmers believe that farmer card can support farmers to obtain subsidized fertilizers, farmers will use farmer card if the image of the issuing bank of farmer card is good, and the farmerswill use farmer card if the requirements or methods are convenient.

There are two dimensions in the perceived behavioral control variable, however, only one dimension has passed the model fit test (control belief). Ajzen (2005) explained that this belief of control leads to the perception whether or not a person has the capacity to carry out behavior is perceived by behavioral control. From the explanation, it can be concluded that the dimension of control belief can already describe the perceived behavioral control. This is in line with research conducted by Ajzen \& Madden (1986) who only asked about control belief dimension to students about the presence of regular classes.

The subjective norm is the variable that has the least influence on the intention of using farmer card with the original sample 0.255. This is in line with the research of Pratiwi and Hartoyo (2014) which explained that subjective norm 
has the least influence to the intention of buying life insurance to the students. Farmers' subjective norm can be seen from farmers' perceptions of social influences or social support. The majority of farmers have moderate subjective norms, which means family, peasant, peasant group leaders advocate using farmer card and the farmer wants to do what the family, peasants, and peasant group leaders advocate.

This research was done when farmer card system have not been implemented yet, hence farmers' behavior in using farmer card could not be measured. In addition, the data obtained is less sensitive because the farmers did not understand the whole issue regarding the farmer card, especially on how to use the farmer card.

\section{Conclusion and Recommendation}

\section{Conclusion}

All of variable in this research, which are attitude toward behavior, subjective norm, and perceived behavioral control, are significant. Those variables have positive effects to the intention of using farmer card. Attitude toward behavior has the largest influence in farmers intention of using farmer card, while subjective norm has the least influence in farmers intention of using farmer card.

\section{Recommendation}

Based on the result, further socialization from field extension farmer is needed regarding farmer card thus farmers can provide better assessment to farmer card. Having the head of the farmer group is very important in this case, as the head of the farmer group can invite more farmer members. In addition, the government needs to implement programs that facilitate farmers, especially farmer card program, to build farmers' confidence to implement the program. After the farmer card program is implemented, the next researcher should be able to add variable of behavior to know the numbers of farmer card users and nonusers.

\section{References}

Ajzen I. (2005). Attitudes, personality, and behavior. Manstea T, editor. England: Open University Press.

Ajzen, I., \& Madden, T. J. (1986). Prediction of goal directed behavior: Attitudes, intentions, and perceived behavioral control. Journal of Experimental Social Psychology, 22, 453-474.

Alzahrani, A. I., Mahmud, I., Ramayah, T., Alfarraj, O., \& Alalwan, N. (2017). Extending the theory of planned behavior (TPB) to explain online game playing among Malaysian undergraduate students. Journal Telematics and Informatics, 34(4), 239-251.doi:10.1016/j.tele.2016.07.001.

Burhanudin. (2015). Aplikasi theory of planned behavior pada intensi mahasiswa untuk berwirausaha. Jurnal Bisnis dan Ekonomi, 6(1), 60-72. 
[BPPSDMP] Badan Penyuluh dan Pengembangan SDM Pertanian. (2017). Petunjuk pelaksanaan verifikasi dan validasi data petani berbasis simluhtan. Jakarta: Kementrian Pertanian.

[BPS] Badan Pusat Statistik. (2015). Penduduk Indonesia hasil survei penduduk antar sensus 2015. Jakarta: Badan Pusat Statistik.

[BPS] Badan Pusat Statistik. (2016). Produksi padi, jagung, dan kedelai (angka sementara tahun 2015). Jakarta: Badan Pusat Statistik.

[BPS] Badan Pusat Statistik. (2017). Kabupaten Bandung dalam angka. Jakarta: Badan Pusat Statistik.

Chen, C. D., Fan, Y. W., \& Farn, C. K. (2007). Predicting electronic toll collection service adoption: An integration of the technology acceptance model and the Theory of Planned Behavior. Transportation Research Part C: Journal Emerging Technologies, 15(5), 300311.doi:10.1016/j.trc.2007.04.004.

Garson, G. D. (2016). Partial least square: regression \& structural equation models. North Carolina State University.

Hair Jr, J. F., Hult, G. T. M., Ringle, C., \& Sarstedt, M. (2013). A primer on partial least squares structural equation modeling (PLS-SEM). Sage Publications.

Hakim, L. (2012). Ekonomi pertanian. Aceh: Universitas Syiah Kuala.

Hoeksma, D. L., Gerritzen, M. A., Lokhorst, A. M., \& Poortvliet, P. M. (2017). An extended theory of planned behavior to predict consumers' willingness to buy mobile slaughter unit meat. Meat Science, 128, 1523.doi:10.1016/j.meatsci.2017.01.011.

Hsu, C. L., Chang, C. Y., \& Yansritakul, C. (2017). Exploring purchase intention of green skincare products using the theory of planned behavior: Testing the moderating effects of country of origin and price sensitivity. Journal of Retailing and Consumer Services, 34, 145152.doi:10.1016/j.jretconser.2016.10.006.

Hussein, A. S. (2015). Penelitian bisnis dan manajemen menggunakan partial least squares (pls) dengan smartPLS 3.0. Universitas Brawijaya.

Kirana, I., Intan, D. A., \& Yasa, N. N. K. (2013). peran gender dalam memoderasi pengaruh perceived benefit dan perceived cost terhadap niat menggunakan kartu kredit di kota denpasar. Jurnal Ekonomi dan Bisnis, 2(2), 1418-1433.

Kotler \& Keller. (2009). Manajemen pemasaran Jilid 1 edisi 13. Jakarta (ID): Erlangga.

[KPR] Kementrian Pertanian. (2015). Rencana strategis kementrian pertanian tahun 2015-2019. Jakarta: Kementrian Pertanian RI.

[KPR] Kementrian Pertanian. (2017). Kartu tani, era baru sejahterakan petani Indonesia. Kementrian Pertanian RI [internet]. [diunduh2018Jan18]. Tersedia pada http://www.pertanian.go.id/ap_posts/detil/993/2017/06/06/ 18/17/04/Kartu\%20Tani\%20Era\%20Baru\%20Sejahterakan\%20Petani\%20 Indonesia.

[KPR] Kementrian Pertanian. (2017). Statistik harga komditas pertanian tahun 2017. Jakarta: Kementrian Pertanian RI.

Lestari, B. A., Suharjo, B., \& Muflikhati, I. (2017). Minat kepemilikan kartu kredit (studi kasus Kota Bogor). Jurnal Aplikasi Bisnis dan Manajemen, 3(1), 143-151.doi:10.17358/jabm.3.1.143. 
Moko, K. W. (2017). Persepsi petani terhadap program kartu tani di Kecamatan Kalijambe Kabupaten Sragen (skripsi). Universitas Sebelas Maret, Surakarta, Indonesia.

Pratiwi, N. A., \& Hartoyo, H. (2014). Analisis niat beli asuransi jiwa pada mahasiswa: aplikasi Theory of Planned Behavior. Jurnal Ilmu Keluarga dan Konsumen, 7(1), 58-66.doi:10.24156/jikk.2014.7.1.58.

Prihandoko, Jahi, A, Gani, D. S., Purnaba, I. G. P., Adrianto, L., \& Tjitradjaja, I. (2012). Faktor-faktor yang mempengaruhi perilaku nelayan artisanal dalam pemanfaatan sumberdaya perikanan di Pantai Utara Provinsi Jawa Barat. Jurnal Penyuluhan, 9(2), 158-173.doi:10.7454/mssh.v15i2.1418.

Ruditya, A. N., \& Chalidyanto, D. (2015). Hubungan Karakteristik Individu terhadap Penilaian Kualitas Produk Apotek Rawat Jalan. Jurnal Administrasi Kesehatan Indonesia, 3(2), 108-117.

Schuh, S., dan J, Stavins. (2010). Why are (some) consumers (finally) writing fewer checks? the role of payment characteristics. Journal of Banking and Finance, 34 (2), 1745-1758.

Sulistiyarini, S. (2013). Pengaruh minat individu terhadap penggunaan mobile banking: model kombinasi Technology Acceptance Model (TAM) dan Theory of Planned Behavior (TPB). Jurnal Ilmiah Mahasiswa FEB, 1(2).

Sumarwan, U. (2011). Perilaku Konsumen. Bogor (ID): Ghalia Indonesia.

Vinzi, V. E., Trinchera, L., \& Amato, S. (2010). PLS path modeling: from foundations to recent developments and open issues for model assessment and improvement. In Handbook of partial least squares (pp. 47-82). Springer, Berlin, Heidelberg.

Wang, S.W., Hsu, M. K. (2016). Airline co-branded credit cards-an application of the theory of planned behavior. Journal of Air Transport Management, 55, 245-254.doi:10.1016/j.jairtraman.2016.06.007.

Wiratmadja, I. I., Nurjanah, N., Kurniawati, A. (2017). Model penerimaan petani terhadap teknologi sistem pertanian organik di Kabupaten Tasikmalaya. Journal of Technology Management, 16(1), 81-91.

Wiyanti, Y. D., Untoro, W. (2016). Prediktor intensi penggunaan internet dalam melakukan pembelian online. Jurnal Economia, 12(2), 146158.doi:10.21831/economia.v12i2.9822.

Yakasai, A. B. M., \& Jusoh, W. J. W. (2015). Testing the Theory of Planned Behavior in determining intention to use digital coupon among university students. Procedia Economics and Finance, 31, 186-193.doi: 10.1016/S2212-5671(15)01145-4.

Yang, K. (2012). Consumer technology traits in determining mobile shopping adoption: An application of the extended theory of planned behavior. Journal of Retailing and Consumer Services, 19(5), 484491.doi:10.1016/j.jretconser.2012.06.003. 